\title{
IN-VITRO UPTAKE OF ZINC BY BOAR SPERMATOZOA*
}

\author{
NELSON WESTMORELAND, N. L. FIRST AND W. G. HOEKSTRA \\ Departments of Biochemistry and of Meat and Animal Science, \\ University of Wisconsin, Madison, Wisconsin, U.S.A.
}

(Received 4th February 1966)

\begin{abstract}
Summary. Boar spermatozoa accumulated zinc when stored in vitro in contact with boar seminal plasma. Zinc uptake was much more rapid when the spermatozoa were stored at $5^{\circ} \mathrm{C}$ than when stored at $30^{\circ} \mathrm{C}$. Freezing or the addition of the membrane-damaging agents, filipin or digitonin, before storage at $30^{\circ} \mathrm{C}$, caused rapid zinc uptake, but addition of the metabolic inhibitors, fluoride or iodoacetate did not accelerate zinc uptake. It is concluded that when membrane damage occurs spermatozoa accumulate zinc from the seminal plasma and that zinc content of spermatozoa is dependent on time of sampling after ejaculation, conditions of storage and membrane integrity.
\end{abstract}

\section{INTRODUGTION}

Boar spermatozoa to be used for artificial insemination are damaged by in-vitro storage much more readily than spermatozoa from the bull. Even short-term storage causes a substantial loss in fertility (Stratman, Self \& Smith, 1958; First, Stratman \& Casida, 1963). Boar spermatozoa are infertile after freezing and thawing (Polge, 1956; Settergren, 1958), while bull spermatozoa maintain good fertility. Under appropriate conditions the membranes of spermatozoa are remarkably permeable even to some relatively large molecules such as cytochrome $c$ and hyaluronidase (Mann, 1951). The common means of storage require lowering of the temperature which can cause cold shock, a process believed to damage the membranes (Mann, 1964).

We were interested in the content of some trace-mineral elements, particularly zinc, in boar spermatozoa at ejaculation and during in-vitro storage. It was thought that zinc or some zinc-containing constituent might be lost or taken up and that this might affect the motility or fertilizing ability of the cell. Our studies revealed an extensive uptake of zinc by spermatozoa during storage and this phenomenon was investigated.

In many species, components of the male reproductive tract contain much more zinc than do other tissues (Vallee, 1962); however, the function of this zinc is not known. There are indications that zinc is important to spermatozoa.

* Meat and Animal Science paper No. 437. 
In starfish spermatozoa, release of zinc in small quantities into the sea water has been implicated in the initiation of motility (Fujii, Utida \& Mizuno, 1955). Amino acids in the media of sea urchin spermatozoa help to prevent the deleterious effects of dilution, an effect believed to depend primarily on metal-binding capacity of the amino acids (Tyler \& Rothschild, 1951).

The following experiments were designed to study the amount of zinc in boar semen and the distribution of zinc between spermatozoa and seminal plasma when semen was stored at $5^{\circ} \mathrm{C}$ and $30^{\circ} \mathrm{C}$. Effects of freezing and of various chemical agents were also studied.

\section{MATERIALS AND METHODS}

Twenty-five ejaculates from four boars of three breeds were collected with an artificial vagina. The first and last semen voided were rejected and the spermrich portion was immediately wet-ashed and analysed for zinc.

For studies of zinc uptake during in-vitro storage, ejaculates were collected from four or five boars in each of three trials and the sperm-rich portions were pooled. The pooled ejaculate was then divided and ${ }^{65} \mathrm{ZnC1}_{2}(0.05 \mu \mathrm{c} / \mathrm{ml}$ semen, contributing $0.12 \mu \mathrm{g} \mathrm{Zn} / \mathrm{ml}$ semen) was added to half. A 5-ml zero-time sample was taken from each of the two aliquots and the aliquots were again divided so that semen with and without ${ }^{65} \mathrm{Zn}$ was held at $5^{\circ}$ and $30^{\circ} \mathrm{C}$. Samples $(5 \mathrm{ml})$ were withdrawn at frequent intervals during a 48 -hr storage period.

Each 5-ml sample was centrifuged in a Servall RC-2 centrifuge at 14,900 $\mathrm{g}$ for $10 \mathrm{~min}$. The supernatant was decanted either into a vial for measurement of radioactivity with a crystal scintillation counter or into a Kjeldahl flask for wet-ashing and total zinc analysis. The residue containing the spermatozoa was suspended in de-ionized water and transferred with three rinses of concentrated $\mathrm{HNO}_{3}$ into similar containers.

Samples for zinc analysis were wet-ashed by adding $1 \mathrm{ml}$ concentrated $\mathrm{H}_{2} \mathrm{SO}_{4}$ and $10 \mathrm{ml}$ concentrated $\mathrm{HNO}_{3}$, boiling until only $\mathrm{H}_{2} \mathrm{SO}_{4}$ remained, cooling, adding $10 \mathrm{ml}$ concentrated $\mathrm{HNO}_{3}$ and $1 \mathrm{ml}$ concentrated $\mathrm{HClO}_{4}$ and boiling until only $\mathrm{H}_{2} \mathrm{SO}_{4}$ remained. The digest was quantitatively transferred to a volumetric flask and made to volume with de-ionized water. Zinc was determined with a Perkin-Elmer model 214 atomic absorption spectrophotometer. Acid-washed glassware was used throughout and appropriate blanks contained negligible amounts of zinc.

In an additional trial ${ }^{65} \mathrm{ZnCl}_{2}$ was added to a pooled ejaculate, a 5-ml zero-time sample was taken, and then seven $50-\mathrm{ml}$ aliquots were taken for storage under various conditions. One aliquot was stored at $5^{\circ} \mathrm{C}$; one at $30^{\circ} \mathrm{C}$; and one was frozen in acetone-dry ice, immediately thawed under running water at about $30^{\circ} \mathrm{C}$, and stored at $30^{\circ} \mathrm{C}$. Before storage at $30^{\circ} \mathrm{C}$ the other four aliquots received, respectively, $1 \mathrm{ml}$ of the following agents to give final concentrations of: filipin (Upjohn Co.), $0.0001 \mathrm{~m}$ in $1 \%$ dimethyl sulphoxide; digitonin, $0.001 \mathrm{~m}$; iodoacetate, $0.005 \mathrm{~m}$ as iodoacetic acid; fluoride, $0.01 \mathrm{~m}$ as sodium fluoride.

Motility was judged by microscopic examination after dilution with $2 \cdot 7 \%$ citrate buffer and warming to $37^{\circ} \mathrm{C}$. 


\section{RESULTS}

In the initial study a mean of $31.8 \mu \mathrm{g}$ zinc/ml of semen (range 7.8 to $78.0 \mu \mathrm{g} / \mathrm{ml}$ ) was found in the sperm-rich fractions of the twenty-five ejaculates. The pooled ejaculates in trials 1 to 3 contained 20,18 and $18 \mu \mathrm{g}$ zinc/ml, respectively.

Results of trials 1 to 3 on zinc uptake by spermatozoa during storage are shown in Text-fig. 1. In each trial zinc was taken up by the spermatozoa from the seminal plasma during in-vitro storage. This zinc uptake occurred much
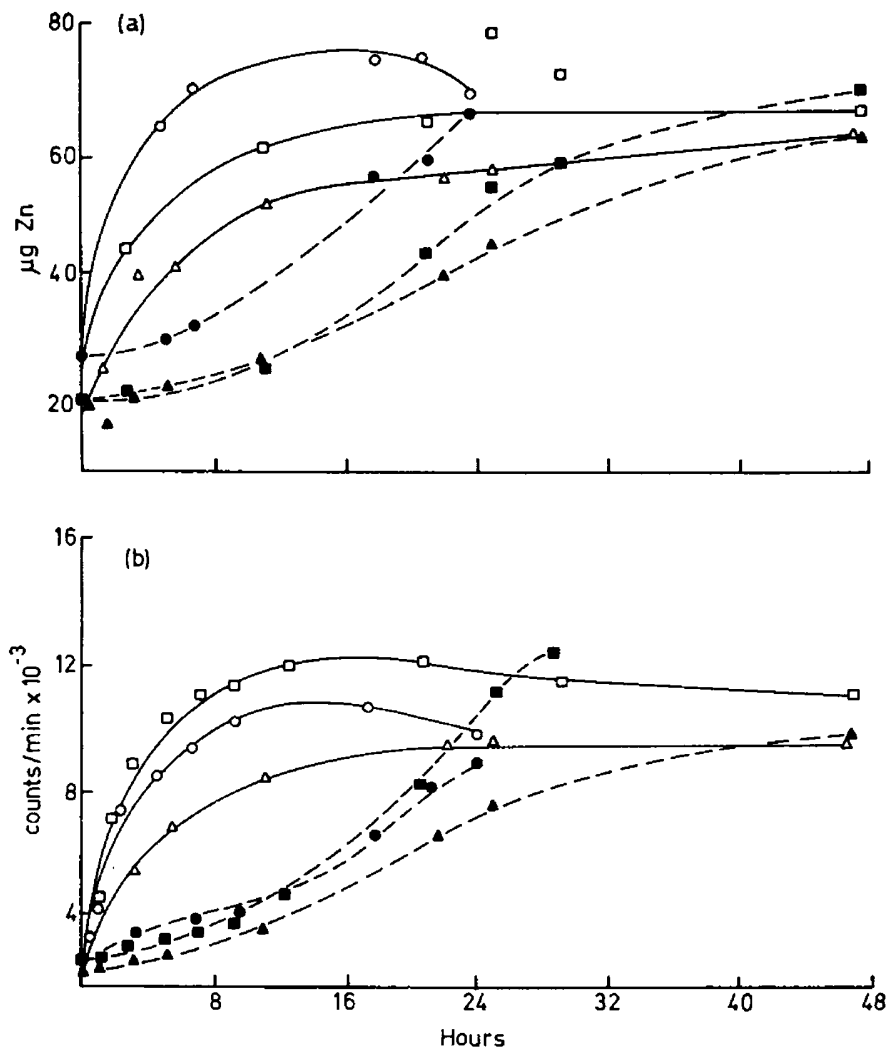

TEXT-FIG. 1. Total zinc content (a) and ${ }^{65} \mathrm{Zn}$ uptake (b) of boar spermatozoa during storage in seminal plasma at $5^{\circ} \mathrm{C}(\longrightarrow)$ and $30^{\circ} \mathrm{C}(\ldots-)$. Each point on the total zinc graph represents the amount of zinc in the sedimented spermatozoa from a 5-ml aliquot of semen. Each point on the ${ }^{65} \mathrm{Zn}$ graph represents the mean counts per minute in the sedimented spermatozoa from two separate $5-\mathrm{ml}$ samples of semen. Samples stored at $5^{\circ} \mathrm{C}$ are represented by solid lines connecting open symbols; samples stored at $30^{\circ} \mathrm{C}$ are represented by broken lines connecting solid symbols. Trial 1 ( $O$ and $\bullet$ ), trial 2 ( $\square$ and E), trial 3 ( $\Delta$ and $\Lambda$ ).

earlier in samples stored at $5^{\circ} \mathrm{C}$ than in those stored at $30^{\circ} \mathrm{C}$, but the final amounts of zinc accumulated were similar at the two temperatures. Similar curves were also obtained for uptake of total zinc and uptake of added ${ }^{65} \mathrm{Zn}$. Although not presented, measurements of total zinc and ${ }^{65} \mathrm{Zn}$ in the decanted seminal plasma samples were also made; in each case a curve reciprocal to that for the sedimented spermatozoa was obtained showing loss of zinc or ${ }^{65} \mathrm{Zn}$ from the seminal plasma. 
Results of the final trial are shown in Text-fig. 2. Spermatozoa stored at $5^{\circ} \mathrm{C}$ and $30^{\circ} \mathrm{C}$ had ${ }^{65} \mathrm{Zn}$ uptakes similar to those found in the first three trials. Frozen spermatozoa and those which had been treated with the membrane damaging agents, filipin or digitonin, and subsequently stored at $30^{\circ} \mathrm{C}$, showed

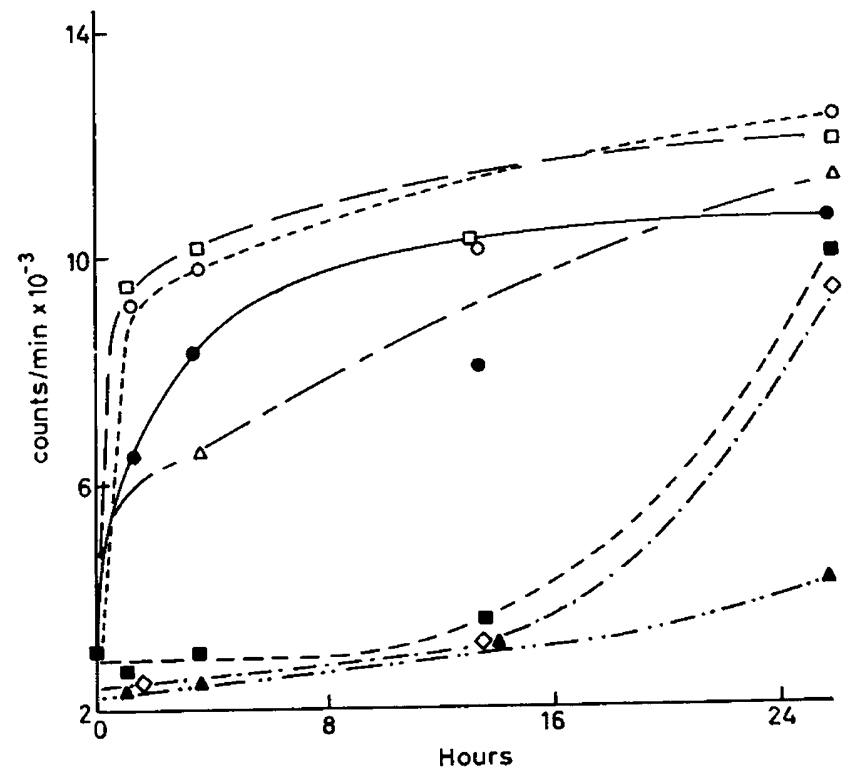

Text-FIG. 2. Effects of storage temperature, freezing, metabolic inhibitors and membrane-damaging agents on ${ }^{65} \mathrm{Zn}$ uptake by boar spermatozoa stored in seminal plasma. Each point represents the counts/min in the sedimented spermatozoa from one $5-\mathrm{ml}$ sample of semen. The treatments and symbols are as follows: Filipin, $0.0001 \mathrm{M}, 30^{\circ} \mathrm{C}$ (O); digitonin, $0.001 \mathrm{M}, 30^{\circ} \mathrm{C}(\square)$; frozen, then $30^{\circ} \mathrm{C}(\triangle) ; 5^{\circ} \mathrm{C}(\odot) ; 30^{\circ} \mathrm{C}(\mathbf{\square})$; fluoride, $0.01 \mathrm{~m}, 30^{\circ} \mathrm{C}(\diamond)$; iodoacetate, $0.005 \mathrm{~m}, 30^{\circ} \mathrm{C}(\Delta)$.

TABLE 1

MOTILITY OF SPERMATOZOA STORED AT $5^{\circ} \mathrm{C}$ AND $30^{\circ} \mathrm{C}$

\begin{tabular}{c|c|c}
\hline \multirow{2}{*}{ Hours of storage } & \multicolumn{2}{|c}{ Motility* $^{*}$} \\
\cline { 2 - 3 } & $5^{\circ} \mathrm{C}$ & $30^{\circ} \mathrm{C}$ \\
\hline 0 & 85 & 85 \\
3 & 25 & 45 \\
5 & 10 & 25 \\
9 & 3 & 25 \\
17 & 1 & 10 \\
24 & 1 & 3 \\
\hline
\end{tabular}

* Estimated full motility represented by 100 .

rapid ${ }^{65} \mathrm{Zn}$ uptake similar to that for samples stored at $5^{\circ} \mathrm{C}$. However, the metabolic inhibitors, fluoride and iodoacetate, did not accelerate ${ }^{65} \mathrm{Zn}$ uptake of spermatozoa stored at $30^{\circ} \mathrm{C}$.

Motility data for $5^{\circ} \mathrm{C}$ and $30^{\circ} \mathrm{C}$ storage are shown in Table 1 . All other treatments resulted in immediate immotility. 


\section{DISCUSSION}

The values for total zinc in sperm-rich boar semen place it in an intermediate position between ram (Mann, 1964) or bull (analyses from this laboratory) semen which contain approximately $10 \mu \mathrm{g}$ zinc/ml and human semen containing from 50 to $200 \mu \mathrm{g}$ zinc/ml (Bertrand \& Vladesco, 1921).

Boar spermatozoa accumulated zinc from the seminal plasma under all conditions tested. However, this uptake occurred much more rapidly at $5^{\circ} \mathrm{C}$ than at $30^{\circ}$ C. Since spermatozoa became immotile sooner when stored at $5^{\circ} \mathrm{C}$, we decided to add agents that cause immediate immotility to see if totally quiescent spermatozoa demonstrate this rapid uptake of zinc. This was shown not to be the case. Treatment of spermatozoa with filipin or digitonin or by freezing did cause rapid uptake of zinc, but fluoride and iodoacetate (Lardy \& Phillips, 1943), which damage by poisoning several enzyme systems, did not accelerate uptake. All these treatments made the cells immediately immotile. Filipin (Demel, van Deenen \& Kinsky, 1965) and digitonin (Cooper \& Lehninger, 1956) are known to damage cell membranes apparently by specific interaction with sterols.

We believe that membrane damage exposes strong binding sites for zinc and thereby causes boar spermatozoa to accumulate zinc from seminal plasma. The fact that a similar accumulation of zinc occurs after 'cold shock' (storing at $5^{\circ} \mathrm{C}$ or freezing, followed by storage at $30^{\circ} \mathrm{C}$ ) makes us believe that membrane damage may also occur under these conditions.

It is possible that this phenomenon might be used as an indication of membrane damage to stored boar spermatozoa.

Morton (1965) found that filipin and digitonin at the levels used here damaged the membranes of bull spermatozoa so that they stained 'dead' with 'live-dead' stain, but that the cells were still capable of respiration and oxidative phosphorylation. In the present studies 'live-dead' staining techniques (Eosin Y-Opal Blue, also Erythrosin B-Fast Green FCF) gave equivocal results, as were also observed with boar sperm by Shelby \& Foley (1964).

Because added ${ }^{65} \mathrm{Zn}$ was taken up at a rate similar to that for zinc already in the seminal plasma, it appears that added ${ }^{65} \mathrm{Zn}$ ions quickly equilibrated with zinc of the seminal plasma.

Preliminary work showed that magnesium content did not change in either spermatozoa or seminal plasma during storage at $5^{\circ} \mathrm{C}$. Therefore this phenomenon is not general for all divalent cations.

Other types of cells have been shown to take up added zinc when studied in vitro. Sastry, Viswanathan, Ramaiah \& Sarma (1960) found that equine erythrocytes accumulated ${ }^{65} \mathrm{Zn}$ from iso-osmotic NaCl. Most of the zinc was bound strongly to intracellular proteins. Puffer fish liver slices have also been found to accumulate added zinc (Saltman \& Boroughs, 1960). In neither study was membrane integrity implicated, but the present studies suggest that this may have also been important in those systems. In the present studies with spermatozoa the zinc was accumulated from a biological secretion rather than from an artificial medium.

The content of zinc in spermatozoa would appear to depend on time of 
sampling after ejaculation, on conditions of storage, and on membrane integrity; values in the literature should thus be viewed with suspicion unless these factors are defined.

The uptake of zinc accompanying membrane damage may be deleterious to boar spermatozoa. Alternatively, the phenomenon may have a counterpart in the process of fertilization; the present studies provide no information on this.

\section{ACKNOWLEDGMENTS}

The authors express thanks to Dr Bruce Morton for helpful suggestions and discussion, and to Dr H. A. Lardy for the supply of filipin.

This work was published with the approval of the Director of the Wisconsin Agricultural Experiment Station, Madison; and was supported in part by Public Health Service Research Grant No. AM-05606 from the National Institute of Arthritis and Metabolic Diseases and by funds from Tri-State Breeders Co-op, Westby, Wisconsin, the American Meat Institute, and Murphy Products Co., Burlington, Wisconsin.

\section{REFERENCES}

Bertrand, G. \& Vladesco, R. (1921) Intervention probable du zinc dans les phénomènes de fécondation chez les animaux vértebrés. C.r. hebd. Séanc. Acad. Sci., Paris, 173, 176.

Cooper, C. \& Lehninger, A. L. (1956) Oxidative phosphorylation by an enzyme complex from extracts of mitochondria. 7. biol. Chem. 219, 489.

Demel, R. A., van Deenen, L. L. M. \& Kinsky, S. C. (1965) Penetration of lipid monolayers by polyene antibiotics. F. biol. Chem. 240, 2749.

First, N. L., Stratman, F. W. \& Casida, L. E. (1963) Effect of sperm age on embryo survival in swine. 7. Anim. Sci. 22, 135.

Fujir, T., Utida, S. \& Mizuno, T. (1955) Reaction of starfish spermatozoa to histidine and certain other substances considered in relation to zinc. Nature, Lond. 176, 1068.

Lardy, H. A. \& Phillips, P. H. (1943) Inhibition of sperm respiration and reversibility of the effects of metabolic inhibitors. F. biol. Chem. 148, 333.

MANN, T. (1951) Studies on the metabolism of semen; cytochrome in human spermatozoa. Biochem. $\mathcal{F}$. $48,386$.

MANN, T. (1964) Biochemistry of semen and of the male reproductive tract. Methuen, London.

Morton, B. (1965) Studies of sperm metabolism. Ph.D. thesis, University of Wisconsin.

Polge, G. (1956) Artificial insemination in pigs. Vet. Rec. 68, 62.

Saltman, P. \& Boroughs, H. (1960) The accumulation of zinc by fish liver slices. Archs Biochem. Biophys. 86, 169.

Sastry, K. S., Viswanathan, L., Ramaiah, A. \& Sarma, P. S. (1960) Studies on the binding of ${ }^{65} \mathrm{Zn}$ by equine erythrocytes in vitro. Biochem. F. 74, 561 .

Settergren, I. (1958) Försök med djupfrysning avgaltsperma till $-79^{\circ} \mathrm{C}$. Experiments on the deepfreezing of boar semen to $-79^{\circ}$ C. (in Swedish). Nordiska veterinärmötet. 80, 26.

Shelby, D. R. \& Foley, C. W. (1964) Differentiating between live and dead boar sperm. F. Anim. Sci. $23,1228$.

Stratman, F. W., Self, H. L. \& Smith, V. R. (1958) Fertilization rates obtained with boar semen stored for zero and twelve hours. F. Anim. Sci. 17, 598.

Tyler, A. \& LoRd Rothschild (1951) Metabolism of sea urchin spermatozoa and induced anaerobic motility in solutions of amino acids. Proc. Soc. exp. Biol. Med. 76, 52.

Vallee, B. L. (1962) Mineral metabolism, Vol. II, Part B, p. 451. Eds C. L. Comar and F. Bronner. Academic Press, New York. 